\title{
Application of Phage Display in Selecting Tomato spotted wilt virus-Specific Single-Chain Antibodies (scFvs) for Sensitive Diagnosis in ELISA
}

\author{
Remko A. Griep, Marcel Prins, Charlotte van Twisk, Hans J. H. G. Keller, Randolf J. Kerschbaumer, \\ Richard Kormelink, Rob W. Goldbach, and Arjen Schots
}

First, third, fourth, and eighth authors: Laboratory for Monoclonal Antibodies, Wageningen Agricultural University, P.O. Box 8123 , 6700 ES Wageningen, The Netherlands; second, sixth, and seventh authors: Laboratory of Virology, Wageningen Agricultural University, Binnenhaven 11, 6709 PD Wageningen, The Netherlands; and fifth author: Institute of Applied Microbiology, University for Agriculture, Muthgasse 18, A-1190 Vienna.

Accepted for publication 14 October 1999.

\section{ABSTRACT}

Griep, R. A., Prins, M., van Twisk, C., Keller, H. J. H. G., Kerschbaumer, R. J., Kormelink, R., Goldbach, R. W. and Schots, A. 2000. Application of phage display in Selecting Tomato spotted wilt virus-specific singlechain Fvs for sensitive diagnosis in ELISA. Phytopathology 90:183-190.

A panel of recombinant single-chain antibodies (scFvs) against structural proteins of Tomato spotted wilt virus (TSWV) was retrieved from a human combinatorial scFv antibody library using the novel phage display technique. After subcloning the encoding DNA sequences in the expression vector $\mathrm{pSKAP/S}$, which allowed the scFvs to be expressed as alkaline phosphatase fusion proteins, 17 different $\mathrm{scFv}$ antibodies were ob- tained. Of these, $12 \mathrm{scFvs}$ were directed against the nucleoprotein $(\mathrm{N})$ and 5, putatively, against the glycoproteins (G1 and G2). Five of the Nspecific antibodies cross-reacted with two other tospoviruses (Tomato chlorotic spot virus and Groundnut ringspot virus), but none recognized the more distantly related tospoviruses Impatiens necrotic spot virus, Watermelon silverleaf mottle virus, Iris yellow spot virus, or Physalis severe mottle virus. The successful use of one of the antibodies as coating and detection reagent in a double-antibody sandwich enzyme-linked immunosorbent assay showed the potential of the phage display system in obtaining antibodies for routine TSWV diagnosis.
Tomato spotted wilt virus (TSWV), the representative of the genus Tospovirus within the family Bunyaviridae, is the causal agent (28) of a major viral disease in many crops. With an estimated annual crop loss of over 1 billion U.S. dollars, TSWV ranks among the top 10 of the most detrimental plant viruses worldwide $(8,23)$. The spread of this plant pathogen is difficult to control because it has a wide host range of more than 1,000 plant species, including mono- and dicotyledons of more than 80 families. Tospoviruses are transmitted in a propagative manner by thrips, which over recent years have become resistant to most insecticides. The spherical tospoviral particle (70 to $110 \mathrm{~nm}$ in diameter) contains three structural proteins: a $28-\mathrm{kDa}$ nucleoprotein $(\mathrm{N})$ that is tightly associated with three genomic RNA segments and two glycoproteins of $78 \mathrm{kDa}(\mathrm{G} 1)$ and $58 \mathrm{kDa}(\mathrm{G} 2)$ that are associated with the viral envelope. Furthermore, low amounts (10 to 20 copies per virion) of the viral polymerase $(331 \mathrm{kDa})$ are present in the virus particle.

Few durable resistance genes against tospoviruses are available for conventional breeding purposes (23). TSWV resistance has been obtained by transgenic expression of the nucleoprotein or movement protein $\left(\mathrm{NS}_{\mathrm{M}}\right)$ gene sequences of TSWV in tobacco (24) and tomato plants (33). However, the use of transgenic plants for production of crops has been limited, and epidemics of tospoviruses are still prevented by sanitary measures in combination with surveillance of disease development. Therefore, to prevent the spread of tospoviruses, diagnostic assays like enzyme-linked immunosorbent assay (ELISA) or polymerase chain reaction (PCR) have to be developed that are suitable for rapid detection of

Corresponding author: A. Schots; E-mail address: Arjen.Schots@1ma.nema.wau.nl

Publication no. P-1999-1221-01R

(c) 2000 The American Phytopathological Society infected plants and, moreover, can be used for certification of plantpropagation materials.

High-quality polyclonal antisera have been raised against several established members of the genus Tospovirus (Table 1) including TSWV (7), Groundnut ringspot virus (GRSV) (5), Impatiens necrotic spot virus (INSV) (20), Tomato chlorotic spot virus (TCSV) (5), and Watermelon silverleaf mottle virus (WSMV) (36). These antisera are now widely applied for tospovirus detection and, with the aid of a double-antibody sandwich (DAS)ELISA $(9,35)$, they form a good compromise between sensitivity, ease, and cost of application. However, the polyclonal antisera are generally based on $\mathrm{N}$-specific antibodies and recognize mainly the species against which they were raised. Thus far, members of the genus Tospovirus have been classified into four distinct serogroups $(1,6)$ (Table 1) that are a direct reflection of the sequence homologies (50 to 80\%) of the $\mathrm{N}$ protein within the different tospovirus species (5). The glycoproteins, on the other hand, are more conserved because they share common epitopes, and polyclonal antibodies raised against the glycoproteins of one virus species also detect others (2). However, the $\mathrm{N}$ protein is by far the most abundant viral protein in infected plants and tospoviruses and, moreover, tends to lose its envelop during several passages in plants (25); therefore, this protein remains the target of interest for serological detection purposes.

Polyclonal antisera, although widely used in routine diagnosis, are available in limited amounts and the specificity varies from batch to batch. Therefore, they are increasingly replaced by monoclonal antibodies (MAbs), because these defined reagents can be produced indefinitely (19). In contrast to polyclonal antibodies, MAbs recognize single epitopes and may allow escape of viruses that lack those epitopes. To guarantee durable recognition of TSWV in the future, antibodies against conserved epitopes are 
required. Several MAbs have been raised against TSWV $(1,16$, 26,29). However, new serogroups are still being established (Table 1) (e.g., Iris yellow spot virus [IYSV; 4] and Physalis severe mottle virus [PSMV; R. Kormelink, unpublished data]); therefore, there is a need for expansion of the available panel of MAbs that can be used for serological detection.

Recombinant antibody technology in combination with the novel phage display technology $(15,22)$ (Fig. 1) provides an extremely useful approach for the production of target-specific antibodies $(13,34)$. Thus far, highly specific antibodies have already been obtained in this way against several important plant pathogens $(11,12$, $14,30,37)$ without the use of laboratory animals and time-consuming immunization protocols.

In this article, we describe the use of the phage display technique to raise a broad panel of TSWV-specific recombinant antibodies from a human combinatorial antibody library (34). Separate selections were carried out to retrieve recombinant single-chain variable antibody fragments (scFvs) against the major structural proteins of TSWV (i.e., the $\mathrm{N}$ protein and the $\mathrm{G} 1$ and $\mathrm{G} 2$ glycoproteins). The G1 and G2 glycoproteins form heterodimers that are hard to separate without introduction of a denaturing step; therefore, phage antibodies (PhAbs) were selected to either of these proteins. The $\mathrm{scFv}$ encoding genes were retrieved and expressed in Escherichia coli as ready to use antibody-enzyme fusion proteins (10). These were used for characterization of their

TABLE 1. Members of the genus Tospovirus used in this study

\begin{tabular}{llcc}
\hline Species & Aronym & Serogroup & Serotype \\
\hline Tomato spotted wilt virus & TSWV & I & $\ldots$ \\
Tomato chlorotic spot virus & TCSV & II & I \\
Groundnut ringspot virus & GRSV & II & II \\
Impatiens necrotic spot virus & INSV-NL & III & $\ldots$ \\
& INSV-US & III & $\ldots$ \\
Watermelon silverleaf mottle virus & WSMV & IV & $\ldots$ \\
Iris yellow spot virus & IYSV & New & $\ldots$ \\
Physalis severe mottle virus & PSMV & New & $\ldots$ \\
\hline
\end{tabular}

reaction with TSWV and several other tospoviruses. In addition, one of the selected monoclonal scFvs was compared to a TSWVspecific polyclonal rabbit antiserum for its use as a coating and detecting reagent in a DAS-ELISA.

\section{MATERIALS AND METHODS}

Bacterial strains. $E$. coli strain TG1 was used for the panning experiments. Expression of scFv-alkaline phosphatase (AP/S) fusion proteins was performed in XL1-Blue MRF' Kan bacteria (Stratagene, La Jolla, CA).

Purification of TSWV. Infectious virus particles of TSWV Brazilian strain (BR-01) were isolated from systemically infected Nicotiana rustica cv. America leaves according to Gonsalves and Trujillo (9). Purified virions were collected from a 20 to $40 \%$ sucrose gradient, pelleted by centrifugation, resuspended in water, and stored at $-70^{\circ} \mathrm{C}$. Concentration of viral protein was measured using the Biorad protein assay (Biorad, Hercules, Ca).

Purification of viral nucleocapsids. $N$. rustica $\mathrm{cv}$. America plants were inoculated with TSWV (BR-01). After 8 to 18 days, sys-

TABLE 2. The quantity of nucleocapsid (N) and complete Tomato spotted wilt virus (TSWV) was used for coating of immunosorbent tubes in combination with the number of washings applied during the panning procedure ${ }^{a}$

\begin{tabular}{lccc}
\hline $\begin{array}{c}\text { Target, } \\
\text { Panning round }\end{array}$ & $\begin{array}{c}\text { Protein concentration } \\
(\mu \mathrm{g} / \mathrm{ml})\end{array}$ & $\begin{array}{c}\text { Coating for } \\
\text { immunotube }(\mu \mathrm{g})\end{array}$ & $\begin{array}{c}\text { No. of } \\
\text { Washings }\end{array}$ \\
\hline Nucleocapsid & & 200 & 20 \\
1 & 50 & 200 & 20 \\
2 & 50 & 40 & 40 \\
3 & 10 & 4 & 40 \\
4 & 1 & 400 & 20 \\
Intact virion & 100 & 200 & 20 \\
1 & 50 & 34 & 40 \\
2 & 8.5 & 4 & 40 \\
3 & 1 & & \\
4 & & &
\end{tabular}

a Coating per tube: $4 \mathrm{ml}$ of $50 \mathrm{mM} \mathrm{Na}_{2} \mathrm{CO}_{3}$ buffer, $\mathrm{pH} 9.8$.

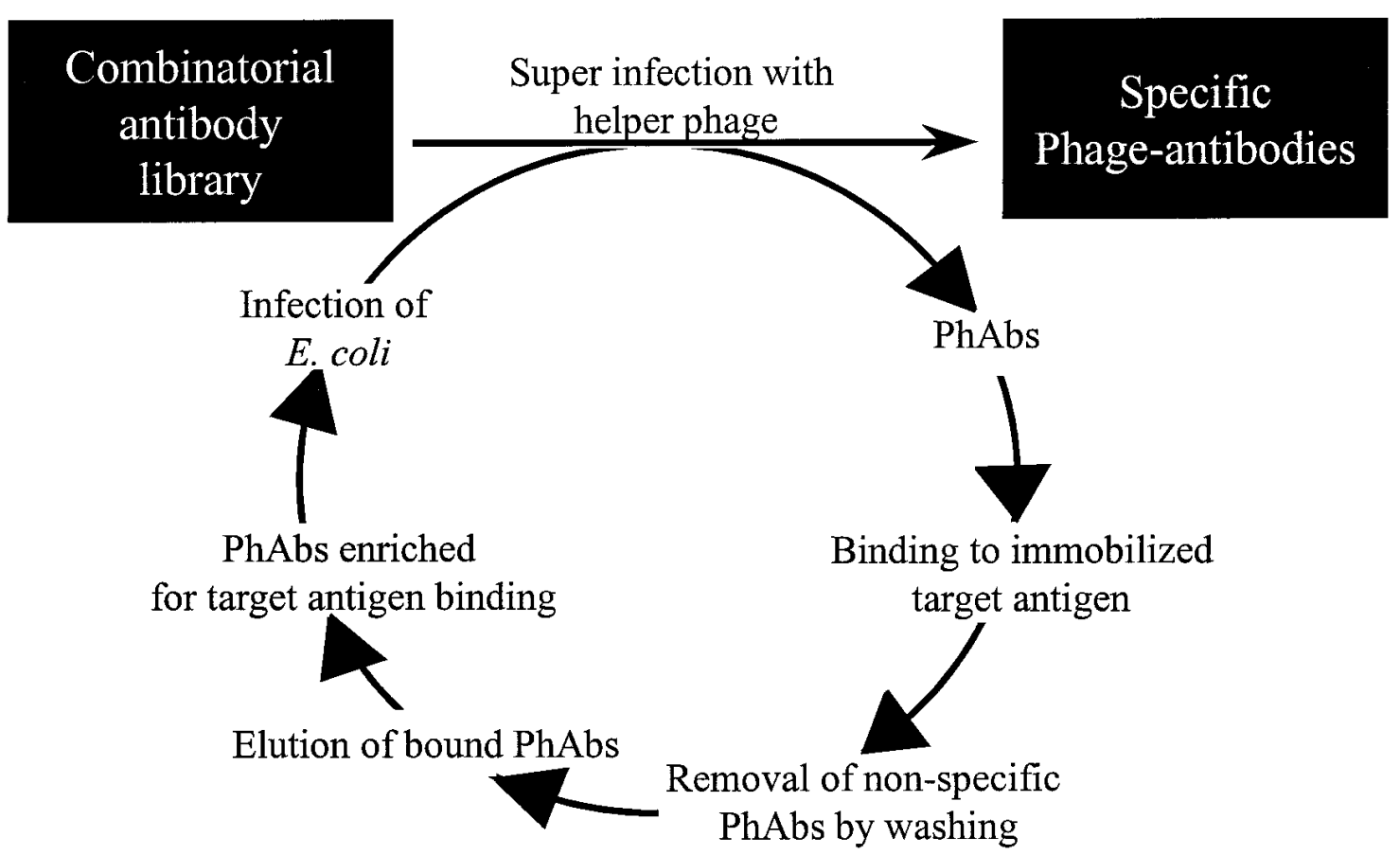

Fig. 1. Outline of the phage display technique. Helper phages, which contain the entire phage genome but lack an efficient packaging signal, are used to "rescue" phagemids from a combinatorial antibody library. When both the helper phage and the single-chain variable fragment (scFv) encoding the phagemid vector are present within the same bacterium, phages are assembled that carry scFv-antibodies (phage antibodies [PhAbs]) on their surface and contain the scFvencoding phagemid vector. Consequently, within PhAbs, the genotype and phenotype are linked. To select for antigen specificity, PhAbs rescued from the combinatorial antibody library are allowed to bind to immobilized target antigens (panning). Washing removes PhAbs that lack affinity for the target antigens. Bound PhAbs are eluted, and selected PhAbs are applied to three sequential rounds of panning to further enhance the percentage of target-reactive PhAbs. 
temically infected leaves were harvested and homogenized $(4 \mathrm{ml} / \mathrm{g})$ in TAS-E buffer (freshly prepared: $0.1 \mathrm{M}$ Tris-HCl, 0.01 M EDTA, $0.01 \mathrm{M} \mathrm{Na}_{2} \mathrm{SO}_{3}, 0.1 \%$ Cysteine, $\mathrm{pH}$ 8.0). The homogenate was filtered through two layers of cheesecloth and put on ice. The filtrate was centrifuged for $10 \mathrm{~min}$ at $1,500 \times g$ at $4^{\circ} \mathrm{C}$ in a GSA rotor, subsequently transferred to Ti45 tubes and centrifuged a second time for $30 \mathrm{~min}$ at $31,000 \times \mathrm{g}$ at $4^{\circ} \mathrm{C}$ in a Ti45 rotor. The pellet containing viral nucleocapsids was resuspended $(0.4 \mathrm{ml} / \mathrm{g})$ in TAS-R buffer (freshly prepared: 0.01 M Tris-HCl, 0.01 M EDTA, 0.01 M $\mathrm{Na}_{2} \mathrm{SO}_{3}, 0.1 \%$ Cysteine, $0.01 \mathrm{M}$ glycine, $1 \%$ Nonidet $\mathrm{P} 40, \mathrm{pH}$ 7.9) while gently stirring for 1 to $2 \mathrm{~h}$ at $4{ }^{\circ} \mathrm{C}$. A volume of $10 \mathrm{ml}$ of the nucleocapsid material was diluted to $30 \mathrm{ml}$ with TAS-R buffer and layered on a $30-\mathrm{ml} 30 \%$ sucrose cushion $(30 \%$, wt/vol, sucrose in TAS-R buffer). After centrifuging for $2.5 \mathrm{~h}$ at $61,000 \times g$ at $4{ }^{\circ} \mathrm{C}$ in a Ti45 rotor, the supernatant was decanted, and the nucleocapsid pellet was resuspended overnight in phosphate-buffered saline (PBS) and stored at $-70^{\circ} \mathrm{C}$ until further use. The concentration of $\mathrm{N}$ protein was measured by the Biorad protein assay.

Preparation of virus-infected plant material for ELISA. Approximately two weeks after inoculation of $N$. benthamiana plants with tospoviruses GRSV (SA-05), INSV (US-01), INSV (NL-07), IYSV, PSMV, TCSV (BR-03), TSWV (BR-01), or WMSV (Table 1), systemically infected leaves were harvested and homogenized 1:10, $\mathrm{wt} / \mathrm{vol}$, in extraction buffer ( $1 \mathrm{~g}$ of leaf material per $10 \mathrm{ml}$ of PBS, $2 \%$ polyvinylpyrrolidone) for use in ELISA.

Selection of recombinant antibodies from a combinatorial antibody library. Selection of target-specific $\mathrm{PhAbs}$ (i.e., phages expressing functional $\mathrm{scFv}$ on their surface) from the human combinatorial antibody library (34) was performed according to Griep et al. (12) with a few modifications. Immunosorbent tubes (Maxisorb, Nunc, Roskilde, Denmark) were coated with $4 \mathrm{ml}$ of either purified TSWV or with purified nucleocapsids, diluted in $50 \mathrm{mM}$ $\mathrm{Na}_{2} \mathrm{CO}_{3}, \mathrm{pH} 9.8$, for $18 \mathrm{~h}$ at $4^{\circ} \mathrm{C}$, as indicated (Table 2). The derived $\mathrm{PhAbs}$ were stored at $4^{\circ} \mathrm{C}$ until use in the next panning round or in phage-ELISA.

Subcloning of $\mathrm{ScFv}$ encoding genes in expression vector pSKAP/S. After the fourth round of selection, the XL1-Blue MRF' Kan bacteria were scraped from the plate, and the $\mathrm{scFv}$ encoding phagemids were extracted using a plasmid DNA purification system (Wizard Midiprep, Promega Corp., Madison, WI). Phagemid DNA was digested (27) with HindIII and NotI, and the excised scFv-encoding DNA fragments were gel-purified and subsequently ligated into HindIII/NotI-digested pSKAP/S vector, allowing expression of $\mathrm{scFv}-\mathrm{AP} / \mathrm{S}$ fusion proteins under tight control of the tetracycline promoter (10). The ligation mix was transfected to E. coli XL1-Blue MRF' Kan bacteria, and the cells were grown overnight at $37^{\circ} \mathrm{C}$ under selection pressure of $100 \mu \mathrm{g}$ of ampicillin (Amp) per $\mathrm{ml}$ of Luria-Bertani (LB) agarose (27).

Production and purification of scFv-AP/S fusion proteins. Individual transformants were picked and grown overnight at $28^{\circ} \mathrm{C}$ in LB medium ( $10 \mathrm{~g}$ of peptone $140,5 \mathrm{~g}$ of yeast extract, and $10 \mathrm{~g}$ of $\mathrm{NaCl}$ per liter with Amp added at $100 \mu \mathrm{g} / \mathrm{ml}$ ). Prior to induction, bacteria were diluted $1: 100$ in $2 \mathrm{TY}$ medium $(34 \mathrm{~g}$ of peptone $140,20 \mathrm{~g}$ of yeast extract, and $10 \mathrm{~g}$ of $\mathrm{NaCl}$ per liter with Amp added at $100 \mu \mathrm{g} / \mathrm{ml}$ and $2 \%$ [wt/vol] glucose) and grown at $37^{\circ} \mathrm{C}$. When the cultures had reached late-log phase (optical density [OD] at $600 \mathrm{~nm}$ of 0.9 ) the temperature was decreased to $16^{\circ} \mathrm{C}$ for $1 \mathrm{~h}$. Subsequently, anhydrotetracycline (aTc) was added $(0.2 \mu \mathrm{g} / \mathrm{ml}$ final concentration), and bacteria were grown for an additional $18 \mathrm{~h}$ at $16^{\circ} \mathrm{C}$. Bacterial cells were pelleted and resuspended in a $1 / 20$ culture volume (referring to original culture volume) $50 \mathrm{mM}$ Tris $/ \mathrm{HCl}$, pH 8 buffer, containing 30\% sucrose and $1 \mathrm{mM}$ EDTA. After incubation for $5 \mathrm{~min}$ at $0^{\circ} \mathrm{C}$, the $\mathrm{scFv}$-AP/S fusion proteins were extracted from the periplasm with a $1 / 20$ culture volume (referring to original culture volume) of $5 \mathrm{mM} \mathrm{MgSO}_{4}$ during $45 \mathrm{~min}$ at $0^{\circ} \mathrm{C}$. In some cases, the $\mathrm{scFv}$-AP/S fusion proteins were purified further by immobilized metal affinity chromatography (IMAC) according to Lindner et al. (21).

MvaI-fingerprinting. To analyze the diversity of the recloned scFvs, restriction fragment length polymorphism (RFLP) fingerprinting was performed on PCR-amplified $\mathrm{scFv}$ DNA. Single colonies were selected and grown for $4 \mathrm{~h}$ in $2 \mathrm{TY}$ (Amp at $100 \mu \mathrm{g} / \mathrm{ml}$ ). From these suspensions, $2 \mu \mathrm{l}$ was taken and added to a $48-\mu \mathrm{l} \mathrm{PCR}$ mix containing $2.5 \mu \mathrm{M}$ dNTPs; $0.25 \mathrm{U}$ of Super Taq DNA polymerase (HT Biotechnology, Cambridge, England); $10 \mu \mathrm{M}$ pSKforward (5'-ACT CTA TCA TTG ATA GAG TTA TTT TAC CAC TCC C-3') and $10 \mu \mathrm{M}$ pSK-reverse (5'-TTT ATC GCT AAG AGA ATC ACG CAG AGC GGC G-3') primers; $2 \mathrm{mM} \mathrm{MgCl}_{2}$, and $50 \mathrm{mM}$ Tris/ $\mathrm{HCl}, \mathrm{pH}$ 8. Amplification was performed in a thermal cycler; 25 cycles $\left(1 \mathrm{~min}, 94^{\circ} \mathrm{C} ; 2 \mathrm{~min}, 72^{\circ} \mathrm{C}\right)$ were performed. After PCR amplification, $20 \mu \mathrm{l}$ of the mix was digested with $10 \mathrm{U}$ of restriction enzyme MvaI (Boehringer GmbH, Mannheim, Germany) for $18 \mathrm{~h}$ at $37^{\circ} \mathrm{C}$. Digestion patterns were analyzed on a 3\% FMC Metaphor agarose gel (Epicentre Technologies, Madison, WI).

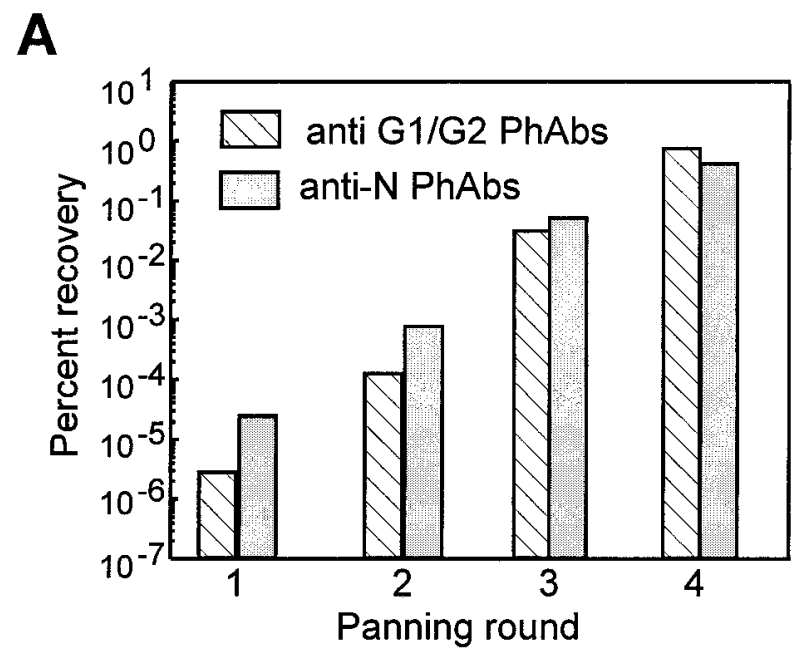

B

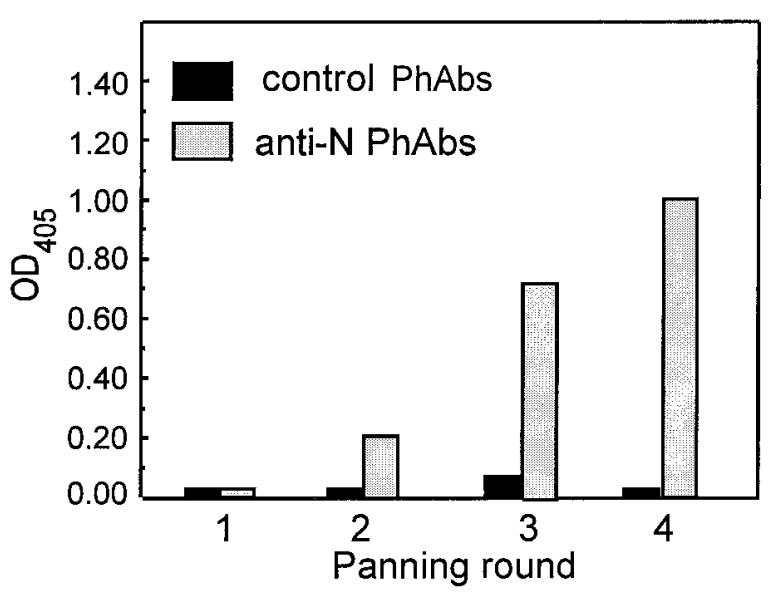

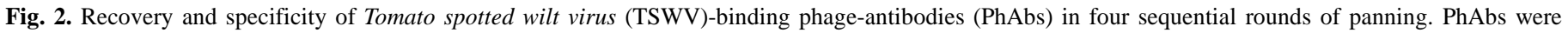

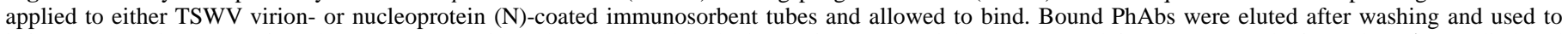

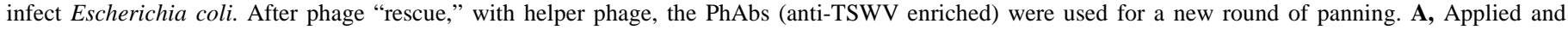

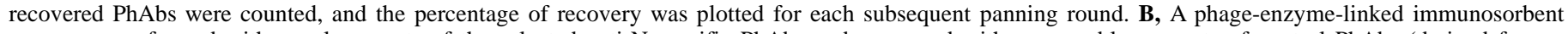

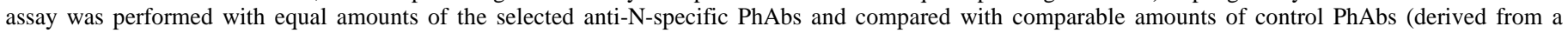
panning against another antigen) to show that the binding was $\mathrm{N}$ specific. 
Phage-ELISA. The phage-ELISA was essentially carried out according to Clark and Adams (3) and Tijsen (32). After each incubation step the microtiter plates were washed four times with PBS containing $0.1 \%$ (vol/vol) Tween-20 (PBST). In brief, ELISA plates (Labstar, Costar, Cambridge, MA) were coated overnight at $4^{\circ} \mathrm{C}$ with purified viral nucleocapsids (100 $\mu \mathrm{l}$ per well), diluted to $2 \mu \mathrm{g} / \mathrm{ml}$ in $0.1 \mathrm{M} \mathrm{Na}_{2} \mathrm{CO}_{3}, \mathrm{pH}$ 9.8. Plates were blocked $(200 \mu \mathrm{l}$ per well) with PBST containing 5\% skimmed milk (PBSTM-5\%) for $30 \mathrm{~min}$ at $37^{\circ} \mathrm{C}$, washed twice with PBST, and subsequently incubated for $1 \mathrm{~h}$ at room temperature with $100-\mu \mathrm{l}$ phage sample dilutions. Nucleoprotein-phage-antibody complexes were detected with monoclonal mouse-anti-M13 antibodies (MAb 12E4, $1 \mu \mathrm{g} / \mathrm{ml}$ in PBSTM-2\%), and finally with polyclonal rat-anti-mouse antibodies conjugated to AP/S (Jackson Immuno-Research Laboratories, Inc., Westgrove, PA) diluted 1:2,500 in PBSTM-2\%. ELISA was developed by adding $100 \mu \mathrm{l}$ of $p$-nitrophenyl phosphate (p-

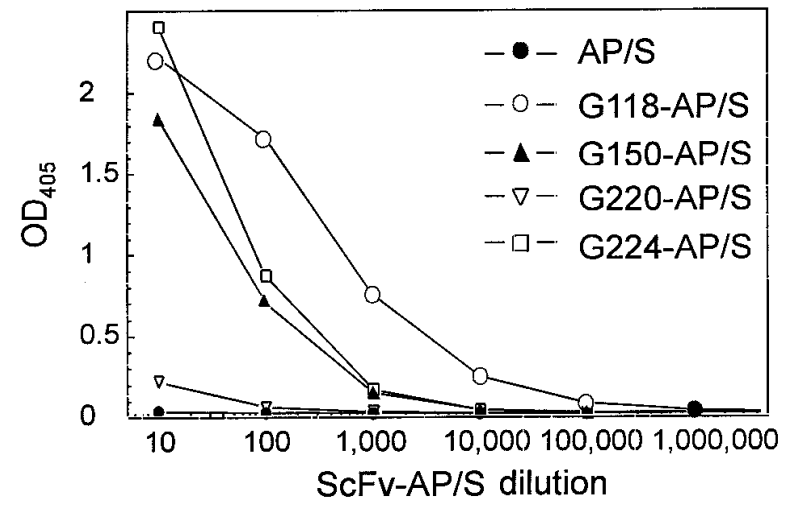

Fig. 3. Reaction of glycoprotein (G1 and G2)-specific single-chain variable antibody (scFv) alkaline phosphatase (AP/S) fusion proteins in antigen-coated plate enzyme-linked immunosorbent assay (ELISA). The G-specific scFv-AP/S fusion proteins were extracted from the periplasm of clones G118, G150, G220, and G224 and applied in serial dilutions into wells of an ELISA plate coated with Tomato spotted wilt virus virions. AP/S without a scFv served as a negative control.
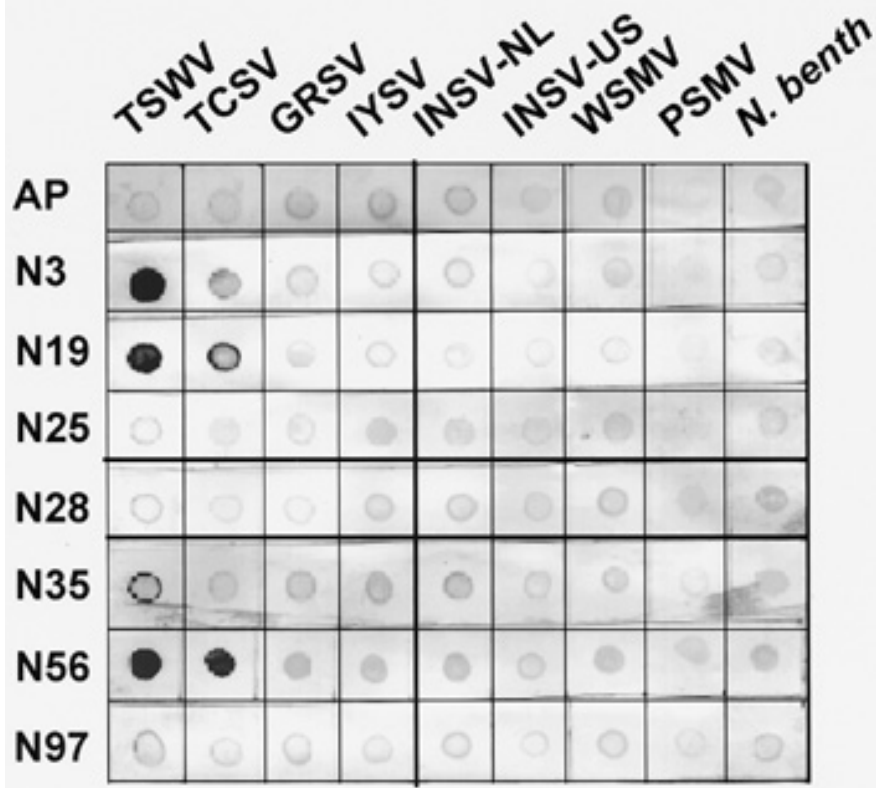

Fig. 4. Reactivity of the Tomato spotted wilt virus (TSWV) nucleocapsidspecific single-chain variable fragment alkaline phosphatase fusion proteins in a dot-immunobinding assay to other tospovirus species. TCSV $=$ Tomato chlorotic spot virus, GRSV = Groundnut ringspot virus, $\mathrm{IYSV}=$ Iris yellow spot virus, INSV = Impatiens necrotic spot virus, WSMV = Watermelon silverleaf mottle virus, PSMV = Physalis severe mottle virus, and $N$. benth $=$ Nicotiana benthamiana.
NPP) substrate per well and scored for positive reactions by an absorbance reading at $405 \mathrm{~nm}$, usually within $60 \mathrm{~min}$.

Antigen-coated plate ELISA. An antigen-coated plate (ACP)ELISA was used to assess the specificity of the recombinant scFvantibodies, according to standard methods $(3,32)$, in which the plates were washed four times with PBST between each incubation step. In brief, ELISA plates were coated with either TSWV virions or with purified nucleocapsids, both diluted to $2 \mu \mathrm{g} / \mathrm{ml}$ in $0.1 \mathrm{M} \mathrm{Na}_{2} \mathrm{CO}_{3}$. After blocking with PBSTM-5\% for $30 \mathrm{~min}$ at $37^{\circ} \mathrm{C}$, the plates were incubated for $1 \mathrm{~h}$ at $37^{\circ} \mathrm{C}$ with recombinant antiTSWV scFv-AP/S fusion proteins, diluted 1:1 in PBTM-4\% or with PcA-BR01-AP (AP/S conjugated polyclonal rabbit antibodies, raised against the nucleocapsid of TSWV), diluted 1:2,000 in PBSTM$2 \%$. The reactions were visualized by incubation with p-NPP substrate, and OD was measured at $405 \mathrm{~nm}$ with an ELISA-reader.

DAS-ELISA. A DAS-ELISA was used to assess the reactions of the recombinant $\mathrm{scFv}$-antibodies toward other tospoviruses. Between each incubation step, the plates were washed four times with PBST. In brief, ELISA plates were coated (100 $\mu \mathrm{l}$ per well) for $18 \mathrm{~h}$ at $4^{\circ} \mathrm{C}$ with polyclonal antibodies raised against the nucleocapsid of TSWV, TCSV, GRSV, INSV, IYSV, or a mix, and diluted 1:1,000 in $0.1 \mathrm{M} \mathrm{Na}_{2} \mathrm{CO}_{3}, \mathrm{pH} 9.8$. After blocking (200 $\mu \mathrm{l}$ per well) with PBSTM-5\% for $30 \mathrm{~min}$ at $37^{\circ} \mathrm{C}$, the plates were incubated with homogenates of either healthy or systemically infected $N$. benthamiana leaves. The plates were incubated with anti-TSWV scFvAP/S conjugates diluted 1:1 in PBSTM-4\% (100 $\mu$ per well) for $1 \mathrm{~h}$ at $37^{\circ} \mathrm{C}$. The reactions were visualized by incubation with p-NPP substrate, and OD was measured at $405 \mathrm{~nm}$ with an ELISA-reader.

Western blotting. TSWV proteins were separated by sodium dodecyl sulfate-polyacrylamide gel electrophoresis and transferred to nitrocellulose membranes. Reactive groups on the membrane were blocked with PBSTM-5\%. The reactivity of the scFv toward TSWV glycoproteins was shown by incubation of the western blot with anti-TSWV scFv-AP/S conjugates and staining with bromochloroindolyl phosphate-nitro blue tetrazolium substrate.

\section{RESULTS}

Selection of recombinant TSWV-specific antibodies from a combinatorial antibody library. In order to obtain scFv-antibodies directed against TSWV N protein or G proteins, four successive rounds of selection (panning) were carried out against purified TSWV nucleocapsids or purified virions, respectively (Fig. 1). Although the amount of target antigen for coating was reduced

TABLE 3. Results of double-antibody sandwich enzyme-linked immunosorbent assay in which the plates were coated with a polyclonal Tomato spotted wilt virus nucleoprotein antiserum ${ }^{\mathrm{a}}$

\begin{tabular}{lccccccc}
\hline & \multicolumn{3}{c}{$\mathrm{OD}_{405}{\text { after } 2 \mathrm{~h}^{\mathrm{b}}}$} & & \multicolumn{3}{c}{$\mathrm{OD}_{405}$ after $18 \mathrm{~h}^{\mathrm{b}}$} \\
\cline { 2 - 3 } \cline { 7 - 8 } Clone & $\mathrm{CV}$ & $\mathrm{N}$ & $\mathrm{B}$ & & $\mathrm{CV}$ & $\mathrm{N}$ & $\mathrm{B}$ \\
\hline AP/S & 0.03 & 0.03 & 0.03 & & 0.05 & 0.05 & 0.05 \\
3 & 1.17 & 1.22 & 0.03 & $>3$ & $>3$ & 0.05 \\
13 & 0.14 & 0.18 & 0.03 & & 2.70 & $>3$ & 0.04 \\
19 & 1.01 & 0.96 & 0.03 & $>3$ & $>3$ & 0.05 \\
25 & 0.06 & 0.07 & 0.03 & & 1.16 & 1.6 & 0.04 \\
28 & 0.13 & 0.18 & 0.03 & & 2.58 & 2.80 & 0.12 \\
32 & 0.04 & 0.05 & 0.03 & & 0.43 & 0.55 & 0.04 \\
35 & 0.20 & 0.55 & 0.03 & $>3$ & $>3$ & 0.06 \\
40 & 0.05 & 0.07 & 0.04 & & 0.77 & 1.14 & 0.18 \\
54 & 0.53 & 0.45 & 0.03 & $>3$ & $>3$ & 0.03 \\
56 & 0.81 & 0.97 & 0.03 & $>3$ & $>3$ & 0.04 \\
63 & 0.15 & 0.18 & 0.03 & 2.65 & 2.80 & 0.04 \\
97 & 0.08 & 0.13 & 0.03 & 1.58 & 2.45 & 0.05 \\
\hline
\end{tabular}

a Samples containing complete virions $(\mathrm{CV})$, nucleoprotein $(\mathrm{N})$, or buffer $(\mathrm{B})$ were applied and the binding of the various $\mathrm{N}$-specific scFv-alkaline phosphatase (AP/S) fusion proteins was visualized with $p$-nitrophenyl phosphate substrate.

b Optical density at $405 \mathrm{~nm}\left(\mathrm{OD}_{405}\right)$ after 2 or $18 \mathrm{~h}$ of incubation on substrate. Data were obtained from a representative experiment; standard deviations $(n=2)$ were smaller than 0.1 for all presented data. 
and washing was intensified during the panning procedure (Table 2 ), the recovery of $\mathrm{PhAbs}$ from the immunosorbent tubes showed a strong increase for each subsequent round of selection (Fig. 2A). After four rounds of selection, the specificity of the polyclonal $\mathrm{PhAbs}$ mixture, panned against the nucleocapsid, showed increasing reactivity toward the nucleoprotein in phage-ELISA (Fig. 2B).

Characterization of selected monoclonal ScFv antibodies. To allow efficient characterization of individual $\mathrm{scFv}$-producing clones, the antibody encoding genes were recloned in expression vector pSKAP/S (10) and expressed as scFv-AP/S fusion proteins. When screened in ACP-ELISA, several clones were obtained producing monoclonal scFv-AP/S fusion proteins that bound to TSWV proteins. The $\mathrm{scFv}-\mathrm{AP} / \mathrm{S}$ fusion proteins derived from the panning, carried out against purified TSWV virions, reacted with complete TSWV particles, not with purified nucleocapsids and, therefore, are putatively specific to the glycoproteins. Other scFv-AP/S fusion proteins, all derived from the selection against purified nucleocapsids, reacted with complete TSWV virions as well as with nucleocapsids and, thus, were directed against the $\mathrm{N}$ protein. Further analysis of the selected scFv encoding genes, using RFLP mapping with restriction enzyme $M v a I$, revealed that $5 \mathrm{G}$-specific (G118-AP/S, G150-AP/S, G180-AP/S, G220-AP/S, and G224AP/S) and 12 N-specific (N3-AP/S, N13-AP/S, N19-AP/S, N25AP/S, N28-AP/S, N32-AP/S, N35-AP/S, N40-AP/S, N54-AP/S, N56-AP/S, N63-AP/S, and N97-AP/S) monoclonal scFvs were obtained. These monoclonal scFvs were designated according to their target specificity and the number of the clone producing each $\mathrm{scFv}-\mathrm{AP} / \mathrm{S}$ fusion protein. The diversity was confirmed by DNA sequencing (data not shown). Differences in the expression levels were found for the $\mathrm{scFv}-\mathrm{AP} / \mathrm{S}$ fusion proteins. The production in E. coli of functional $\mathrm{scFv}$-enzyme fusion proteins varied from $<50 \mu \mathrm{g} /$ liter of bacterial culture for the scFv-AP/S fusion-protein of N32 to $4 \mathrm{mg} /$ liter for G118-AP/S.

All glycoprotein-specific fusion proteins reacted in ACP-ELISA with purified TSWV virions. The osmotic shock fraction of G118AP/S (4 mg/ml) gave a positive signal when diluted up to 10,000 times (Fig. 3). However, when homogenates of TSWV-infected N. benthamiana leaves were used for coating in an ACP-ELISA format, only weak reactions were obtained with all G-specific scFv-AP/S fusion proteins. Also, in western blot analyses, only weak reactions, if any, were observed. Hence, it is impossible to obtain conclusive evidence as to whether these antibodies are really glycoprotein-specific and to which of the two G-proteins they bind. The epitopes recognized by these antibodies are apparently sensitive to treatment with SDS.

Reactivity of TSWV-specific scFvs toward other tospoviruses. To analyze whether the selected recombinant antibodies also recognized other tospovirus species in addition to TSWV, they were tested with homogenates of $N$. benthamiana leaves systematically infected with GRSV, INSV, IYSV, PSMV, TCSV, TSWV, or WMSV (Table 1). Although no significant reactions were obtained in ACP-ELISA, except for the homologous reaction with TSWV, positive reactions (Fig. 4) were observed when aliquots of TCSV-infected plant extract were blotted on nitrocellulose and N3-AP/S, N19-AP/S, and N56-AP/S were used for detection. In addition, the G1-reactive fusion protein, G224-AP/S, also reacted in this dot-blot assay, but only with TSWV (data not shown).

To determine whether the different results obtained were due to the ACP-ELISA format, a DAS-ELISA was performed on TSWVinfected leaf material. To this end, ELISA plates were coated with TSWV-specific polyclonal anti-N serum. Samples of TSWVinfected leaf material, purified TSWV nucleocapsids, or TSWV virions were applied and tested for recognition. Results with N-specific scFv-AP/S fusion proteins showed a clear reaction in almost all cases with TSWV-containing samples (Table 3), although some reactions (e.g., N40-AP/S) showed a lower $\mathrm{OD}_{405}$ absorbance, probably due to a lower affinity of this $\mathrm{scFv}-\mathrm{AP} / \mathrm{S}$ protein for the nucleocapsid. The reaction was $\mathrm{N}$ specific, because no reaction above the background was obtained with buffer or when nonconjugated AP/S or G-specific scFv-AP/S fusion proteins were applied.

In concert, a DAS-ELISA was performed in which the plate was coated with each of the N-specific antisera raised against the nu-

TABLE 5. Determination of detection level for nucleocapsids of Tomato spotted wilt virus (TSWV) by double-antibody sandwich enzyme-linked immunosorbent assay (ELISA) in which plates were coated with specific antisera against TSWV nucleocapsids ${ }^{\mathrm{a}}$

\begin{tabular}{lcc}
\hline & \multicolumn{2}{c}{ Antibody-enzyme conjugate } \\
\cline { 2 - 3 } $\begin{array}{l}\text { Nucleocapsids } \\
(\mathrm{ng} / \mathrm{ml})\end{array}$ & $\begin{array}{c}\mathrm{N} 56-\mathrm{AP} / \mathrm{S} \\
(0.1 \mu \mathrm{g} / \mathrm{ml})^{\mathrm{b}}\end{array}$ & $\begin{array}{c}\text { Polyclonal-AP } \\
(0.5 \mu \mathrm{g} / \mathrm{ml})^{\mathrm{c}}\end{array}$ \\
\hline 1,000 & $2.31 \pm 0.102$ & $2.89 \pm 0.015$ \\
500 & $1.98 \pm 0.053$ & $2.51 \pm 0.049$ \\
100 & $0.77 \pm 0.053$ & $1.16 \pm 0.087$ \\
50 & $0.40 \pm 0.057$ & $0.77 \pm 0.041$ \\
10 & $0.14 \pm 0.005$ & $0.32 \pm 0.026$ \\
5 & $0.08 \pm 0.002$ & $0.21 \pm 0.030$ \\
1 & $0.06 \pm 0.004$ & $0.17 \pm 0.004$ \\
$\mathrm{PE}$ & $0.05 \pm 0.01$ & $0.14 \pm 0.03$
\end{tabular}

a Nucleoprotein-specific single-chain N56 fused to alkaline phosphatase (AP/S) and conventional alkaline phosphatase (AP)-conjugated TSWV N-specific polyclonal antibodies were compared. Purified nucleocapsids were diluted in a healthy plant extract (PE).

${ }^{\mathrm{b}}$ ELISA-readings after $2 \mathrm{~h}$ of incubation with $p$-nitrophenyl phosphate substrate at room temperature plus $16 \mathrm{~h}$ at $4^{\circ} \mathrm{C}$.

${ }^{c}$ ELISA-readings after $2 \mathrm{~h}$ of incubation with $p$-nitrophenyl phosphate substrate at room temperature

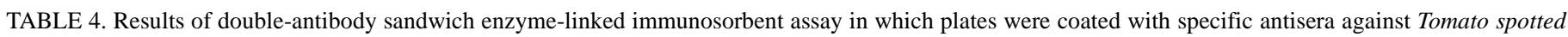
wilt virus (TSWV), Impatiens necrotic spot virus (INSV), Tomato chlorotic spot virus (TCSV), or Groundnut ringspot virus (GRSV) nucleoproteins ${ }^{\text {a }}$

\begin{tabular}{|c|c|c|c|c|c|c|c|c|c|}
\hline \multirow[b]{2}{*}{ Clone } & \multicolumn{4}{|c|}{$\mathrm{OD}_{405}$ after $2 \mathrm{~h}^{\mathrm{b}}$} & \multicolumn{5}{|c|}{$\mathrm{OD}_{405}$ after $18 \mathrm{~h}^{\mathrm{b}}$} \\
\hline & $\mathrm{PE}+\mathrm{TSWV}$ & $\mathrm{PE}+\mathrm{TCSV}$ & PE + GRSV & $\mathrm{PE}+\mathrm{INSV}$ & PE + TSWV & $\mathrm{PE}+\mathrm{TCSV}$ & $\mathrm{PE}+\mathrm{GRSV}$ & PE + INSV & $\mathrm{PE}$ \\
\hline $\mathrm{AP} / \mathrm{S}$ & 0.03 & 0.03 & 0.03 & 0.03 & 0.06 & 0.07 & 0.06 & 0.05 & 0.05 \\
\hline 3 & 1.82 & 0.14 & 0.04 & 0.03 & $>3$ & 2.51 & 0.30 & 0.06 & 0.05 \\
\hline 13 & 0.38 & 0.03 & 0.03 & 0.03 & $>3$ & 0.16 & 0.09 & 0.05 & 0.12 \\
\hline 19 & 1.30 & 0.12 & 0.03 & 0.03 & $>3$ & 2.41 & 0.25 & 0.06 & 0.05 \\
\hline 25 & 0.15 & 0.03 & 0.03 & 0.03 & 2.71 & 0.56 & 0.12 & 0.04 & 0.04 \\
\hline 28 & 0.37 & 0.04 & 0.03 & 0.03 & $>3$ & 0.15 & 0.06 & 0.06 & 0.12 \\
\hline 32 & 0.05 & 0.03 & 0.03 & 0.03 & 0.73 & 0.05 & 0.04 & 0.05 & 0.04 \\
\hline 35 & 0.81 & 0.03 & 0.03 & 0.03 & $>3$ & 0.08 & 0.08 & 0.06 & 0.06 \\
\hline 40 & 0.12 & 0.03 & 0.04 & 0.04 & 2.15 & 0.07 & 0.07 & 0.06 & 0.18 \\
\hline 54 & 1.11 & 0.03 & 0.03 & 0.03 & $>3$ & 0.12 & 0.13 & 0.12 & 0.18 \\
\hline 56 & 1.23 & 0.12 & 0.03 & 0.03 & $>3$ & 2.41 & 0.36 & 0.05 & 0.04 \\
\hline 63 & 0.33 & 0.03 & 0.03 & 0.03 & $>3$ & 0.06 & 0.11 & 0.05 & 0.04 \\
\hline 97 & 0.22 & 0.05 & 0.04 & 0.03 & $>3$ & 0.81 & 0.25 & 0.05 & 0.05 \\
\hline
\end{tabular}

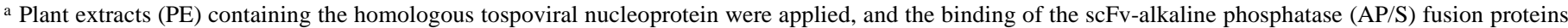
was visualized with $p$-nitrophenyl phosphate substrate.

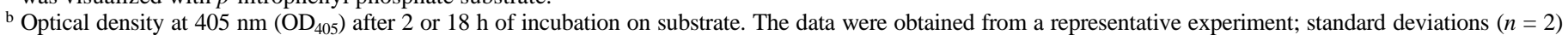
were smaller than 0.1 for all presented data. 

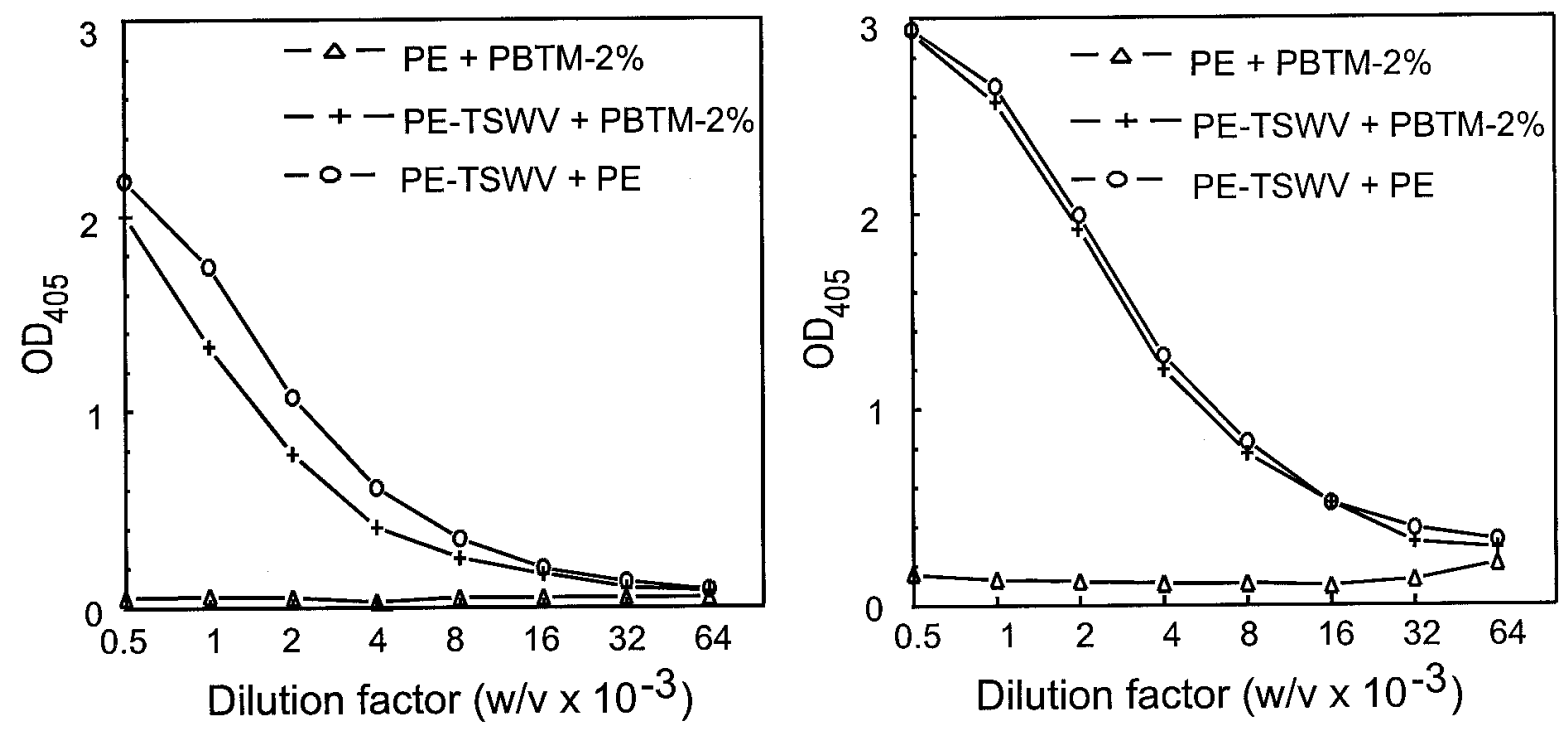

Fig. 5. Determination of the double-antibody sandwich enzyme-linked immunosorbent assay (ELISA) detection limit for nucleocapsid protein (N) in Tomato spotted wilt virus (TSWV)-infected plant extract, as assayed with A, single chain variable fragment antibody alkaline phosphatase (AP/S) fusion protein N56$\mathrm{AP} / \mathrm{S}$ or B, a TSWV N-specific polyclonal antiserum conjugated to alkaline phosphatase. The wells of an ELISA plate, coated with a TSWV N-protein-specific polyclonal antiserum, were incubated with extracts of healthy Nicotiana benthamiana plants (PE) or TSWV-infected $N$. benthamiana plants (PE-TSWV). Serial dilutions of PE and PE-TSWV were made either in PE or in phosphate-buffered saline containing 2\% skim milk powder and 0.1\% Tween-20 (PBTM-2\%). The $\mathrm{N}$-specific polyclonal antiserum AP conjugate was applied at $0.5 \mu \mathrm{g} / \mathrm{ml}$; the fusion protein N56-AP/S was applied at $0.1 \mu \mathrm{g} / \mathrm{ml}$.
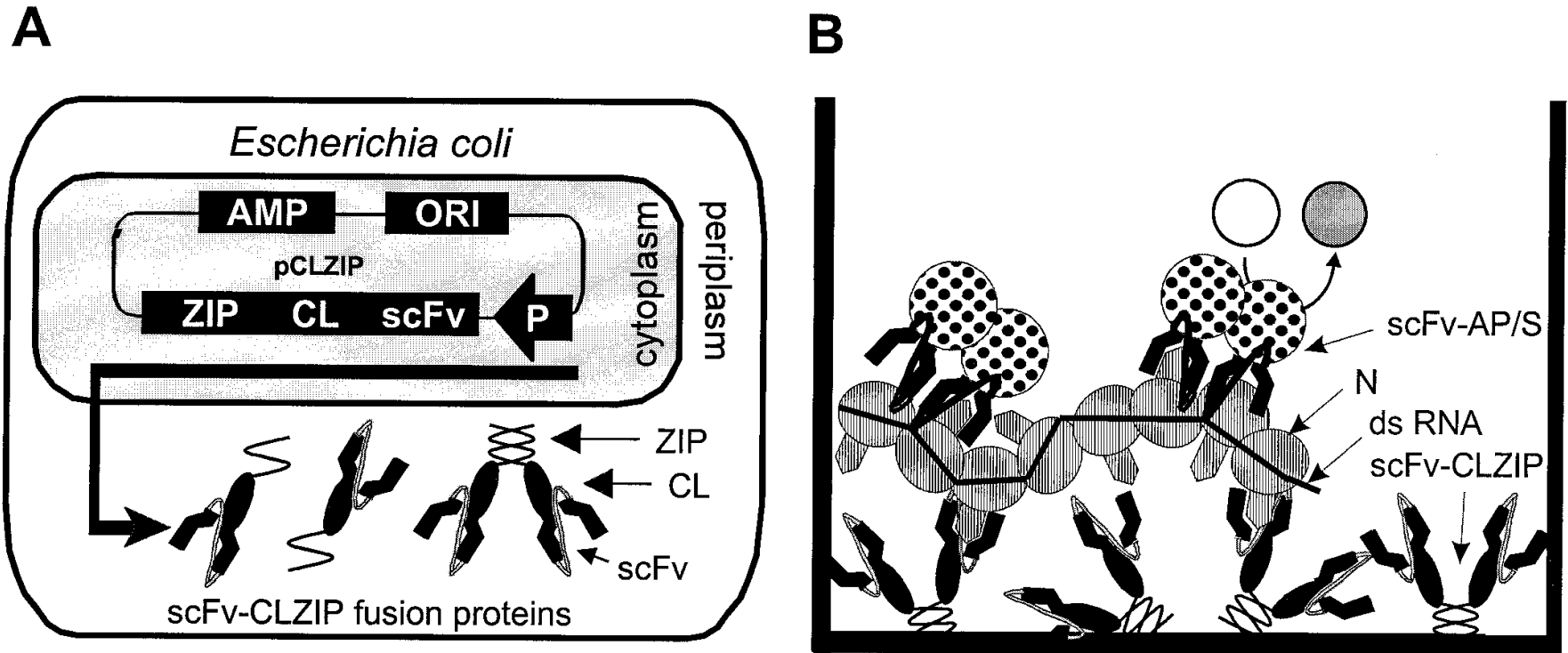

Fig. 6. A, The alkaline phosphatase gene of N56-AP/S was replaced by the constant Kappa light chain domain (CL) and a leucine zipper domain (ZIP). Transformed bacteria produce fusion proteins of single-chain variable antibody fragment (scFv) N56 and the CLZIP domains upon induction. The CLZIP-N56 fusion proteins are secreted into the periplasm where they dimerize. B, CLZIP-N56 fusion proteins can be used to coat the wells of an enzyme-linked immunosorbent assay plate that is subsequently incubated with extracts of Tomato spotted wilt virus (TSWV)-infected Nicotiana benthamiana plants (PETSWV). For detection of captured nucleocapsids (N), an $\mathrm{N}$-specific scFv alkaline phosphatase (scFv-AP/S) fusion protein can be applied.

cleocapsids of six different tospoviruses (Table 1). The results from this ELISA (Table 4) showed clear reactions with TCSV and GRSV in combination with N3-AP/S, N19-AP/S, N25-AP/S, N56-AP/S, and N97-AP/S, although reactions were less intense compared with TSWV. No reactions were observed with any of the more distantly related species, such as INSV, IYSV, PSMV, and WMSV.

Based on the latter results, combined with those obtained in the ACP-ELISA, it is clear that the fusion proteins N3-AP/S, N19$\mathrm{AP} / \mathrm{S}, \mathrm{N} 25-\mathrm{AP} / \mathrm{S}, \mathrm{N} 56-\mathrm{AP} / \mathrm{S}$, and N97-AP/S do recognize TSWV, TCSV, and GRSV in DAS-ELISA but not in ACP-ELISA. Moreover, whereas GRSV is not recognized in ACP-ELISA or dot-blot, this virus is recognized at low efficiency with the aforementioned $\mathrm{scFv}-\mathrm{AP} / \mathrm{S}$ fusion proteins in DAS-ELISA.

Sensitivity in TSWV diagnosis. To test the potential of the monoclonal $\mathrm{scF} v$ antibodies, the broad-reacting N56-AP/S fusion protein, which recognizes serogroup I and II species, was purified and further characterized for its applicability in TSWV diagnosis. Different amounts of TSWV nucleocapsids were diluted into healthy plant extracts of $N$. benthamiana and tested in a DAS-ELISA (Table 5). At a concentration of $0.1 \mu \mathrm{g}$ of N56-AP/S per ml, the detection limit obtained for the $\mathrm{N}$ protein was comparable to the detection limit obtained with the polyclonal antibody AP/S conjugate at $0.5 \mu \mathrm{g} / \mathrm{ml}$. This resemblance in sensitivity also was 
TABLE 6. Comparison of coating and detection efficiency with a combination of conventional Tomato spotted wilt virus (TSWV) nucleoprotein (N)-specific polyclonal antibodies (PAbs) or recombinant antibodies in a double-antibody sandwich enzyme-linked immunosorbent assay ${ }^{\mathrm{a}}$

\begin{tabular}{|c|c|c|c|c|c|c|}
\hline \multirow[b]{3}{*}{ Coating reagent } & \multicolumn{6}{|c|}{ Detection reagent } \\
\hline & \multicolumn{2}{|c|}{ PAb-TSWV-AP $(0.5 \mu \mathrm{g} / \mathrm{ml})$} & \multicolumn{2}{|c|}{ N56-AP/S $(0.1 \mu \mathrm{g} / \mathrm{ml})$} & \multicolumn{2}{|c|}{ N56-AP/S $(1 \mu \mathrm{g} / \mathrm{ml})$} \\
\hline & $\mathrm{PE}$ & PE-TSWV & $\mathrm{PE}$ & PE-TSWV & $\mathrm{PE}$ & PE-TSWV \\
\hline PAb-TSWV N $(0.5 \mu \mathrm{g} / \mathrm{ml})$ & 0.04 & 0.99 & 0.03 & 0.57 & 0.05 & 1.39 \\
\hline CLZIP-56 $(0.1 \mu \mathrm{g} / \mathrm{ml})$ & 0.04 & 0.51 & 0.03 & 0.36 & 0.05 & 0.71 \\
\hline CLZIP-56 (1 $\mu \mathrm{g} / \mathrm{ml})$ & 0.04 & 0.73 & 0.05 & 0.71 & 0.05 & 1.28 \\
\hline
\end{tabular}

${ }^{a}$ Healthy plant extract (PE) or TSWV-infected plant extract (PE-TSWV) was applied at $1 \mathrm{~g} / 20 \mathrm{ml}$ of extraction buffer. Standard deviations obtained with healthy PE were smaller than 0.006; standard deviations obtained with TSWV-infected PE were smaller than 0.1 . AP/S = alkaline phosphatase

observed when serial dilutions of healthy and TSWV-infected $N$. benthamiana homogenates were screened in DAS-ELISA. Whereas samples are tested in routine diagnosis at dilutions of 10 to 100 times, both the scFv-AP/S fusion-protein of N56 (Fig. 5A) and the polyclonal antiserum (Fig. 5B) detected TSWV in extracts of $N$. benthamiana at dilutions up to 1:16,000.

Development of a complete recombinant DAS-ELISA. A DAS-ELISA with the TSWV/N-specific polyclonal antiserum as coating reagent and the N56-AP/S fusion protein for detection was highly sensitive for TSWV (Fig. 5A); however, the use of $\mathrm{scFv}$ N56 as coating reagent was also evaluated. The scFvs are inactivated when coated on ELISA-plates (17); therefore, a construct of scFv N56 was assembled (Fig. 6A) in which the AP/S encoding gene was replaced by a sequence encoding the constant domain of the mouse light-chain (CL), a leucine zipper (ZIP) dimerization domain, and a His(6)-tag (18). The N56-CLZIP protein was purified by IMAC and compared to the polyclonal TSWV/N-specific antiserum for coating efficiency by DAS-ELISA (Fig. 6B). At a coating density of $1 \mu \mathrm{g} / \mathrm{ml}$, the N56-CLZIP fusion protein was equally effective (Table 6), which demonstrates that TSWV can be efficiently detected with a DAS-ELISA that is entirely based on recombinant MAbs.

\section{DISCUSSION}

With the aid of the phage display system, a series of 17 TSWVspecific scFvs was retrieved from the Vaughan combinatorial scFv-antibody library (34) and expressed as scFv-AP/S fusion protein in E. coli. Of these scFv-AP/S fusion proteins, 12 (N3-AP/S, N13-AP/S, N19-AP/S, N25-AP/S, N28-AP/S, N32-AP/S, N35AP/S, N40-AP/S, N54-AP/S, N56-AP/S, N63-AP/S, and N97AP/S) were identified as N-specific and 5 (G118-AP/S, G150-AP/S, G180-AP/S, G220-AP/S, and G224-AP/S) were directed against the glycoproteins of TSWV.

From the series of N-specific scFv-AP/S fusion proteins, N56$\mathrm{AP} / \mathrm{S}$, at a concentration of $0.1 \mu \mathrm{g} / \mathrm{ml}$, could detect as little as $1 \mathrm{ng}$ (Table 5) of $\mathrm{N}$ protein in DAS-ELISA. In addition, the CLZIP fusion protein of scFv N56 was an effective coating reagent (Table 6 ), suggesting that this recombinant $\mathrm{scFv}$ is a promising candidate for development of a complete recombinant diagnostic assay for routine detection of TSWV in plant material.

The antibodies obtained recognized different epitopes of the structural TSWV proteins. The scFv-AP/S obtained from the panning carried out against purified virions (G-series) only reacted with complete TSWV particles, not with nucleocapsids. Hence, these antibodies are putatively directed against the $\mathrm{G}$ proteins, although specificity with the viral polymerase that was present in low amounts cannot be excluded. Of the $\mathrm{N}$-specific scFv-AP/S antibodies, some reacted only with the $\mathrm{N}$ proteins of TSWV, whereas others reacted with an epitope that was present on the N-protein of TSWV, TCSV, and GRSV. The N-encoding genes of the latter isolates have been sequenced and share $\approx 78 \%$ sequence identity (5), but thus far, no scFvs have recognized a common epitope within the $\mathrm{N}$ protein of the different tospovirus species N56-AP/S is one of the few selected MAbs that recognized up to three different tospoviruses (i.e., TSWV, GRSV, and TCSV) and, therefore, must be directed against a common epitope.
Polyclonal TSWV N-specific antisera, and now also some scFv, have been shown to cross-react with TCSV and GRSV isolates. For a universal tospovirus diagnosis system, a $\mathrm{scFv}$ is required that recognizes all tospoviruses, even those that currently escape detection. However, instead of searching for one single universal $\mathrm{scFv}$, broad-reacting MAbs could be pooled to obtain a specific polyclonal antiserum with a defined character and with specificity for all species within the genus Tospovirus.

The data presented in this article demonstrate the feasibility of the phage display technique to select a large panel of TSWV-specific MAbs. It is worth trying to obtain, in a new selection, scFvantibodies that have a broad detection range for tospoviruses. The phage display technique allows selections of $\mathrm{N}$ (or G1 and G2) proteins from different isolates; therefore, it may be possible to guide selection of MAbs toward shared epitopes. After all, selection of MAbs by phage display is not biased to a certain epitope on the basis of immunogenicity but merely by the frequency of occurrence. This means that selection would be for specificity against the most prominent and conserved epitopes within the $\mathrm{N}$ (or G1 and G2) proteins.

The tospoviral $\mathrm{N}$ protein is involved in many viral processes, such as packaging of RNA, replication, movement, and transmission; therefore, an antibody that disrupts epitopes involved in one of these processes may be successful in conferring resistance when expressed in plants. The principle of such "plantibody"-mediated resistance has been shown, with a recombinant MAb against Artichoke crinkled mottle virus, by Tavladoraki et al. (31). The genes encoding the TSWV-specific scFv-antibodies were obtained by the phage display technique; therefore, they can be readily transferred into plants. Moreover, if mutants of TSWV evolve that potentially could overcome the antibody-mediated resistance, new inhibiting antibodies can be raised to ensure durable resistance and, in addition, safeguard detection in plants. After all, the power of the phage display system is the selection of large panels of target-specific scFvs from naive combinatorial libraries, as was shown in the case of TSWV.

\section{ACKNOWLEDGMENTS}

This research was supported by a grant from the Program Committee on Agricultural Biotechnology (PcLB) and E. C. grants AIR3-CT94-1046 and FAIR1-CT95-0905. We thank H. Hoogenboom for allowing us to work at his laboratory (CESAME, Academic Hospital Maastricht, the Netherlands) with the Vaughan antibody library, developed by Cambridge Antibody Technology; and W. B. van Muiswinkel (Wageningen Institute of Animal Sciences, Cell Biology and Immunology Group, Wageningen Agricultural University) for critically reading the manuscript.

\section{LITERATURE CITED}

1. Adam, G., Peters, D., and Goldbach, R. W. 1996. Serological comparison of tospovirus isolates using polyclonal and monoclonal antibodies. Acta Hortic. 431:135-158.

2. Adam, G., Roggero, P. Malavsi, F., and Papa, G. 1995. An approach for a general tospovirus assay by antibodies against natively purified tomato spotted wilt virus G proteins. EPPO Bull. 25:247-257.

3. Clark, M. F., and Adams, A. N. 1977. Characteristics of the microplate method of enzyme-linked immunosorbent assay for the detection of 
plant viruses. J. Gen. Virol. 34:475-483.

4. Cortes, I., Livieratos, I. C., Derks, A., Peters, D., and Kormelink, R. 1998. Molecular and serological characterization of iris yellow spot virus, a new and distinct tospovirus species. Phytopathology 88:12761282.

5. De Àvila, A. C., De Haan, P., Kormelink, R., Resende, R. de O., Goldbach, R. W., and Peters, D. 1993. Classification of tospoviruses based on phylogeny of nucleoprotein gene sequences. J. Gen. Virol. 74:153-159.

6. De Àvila, A. C., Huguenot, C., Resende, R. de O., Kitajima, E. W., Goldbach, R. W., and Peters, D. 1990. Serological differentiation of 20 isolates of Tomato spotted wilt virus. J. Gen. Virol. 71:2801-2807.

7. De Haan, P., Wagemakers, L., Goldbach, R., and Peters, D. 1989. Tomato spotted wilt virus, a new member of the Bunyaviridae? Pages 287290 in: Genetics and Pathogenicity of Negative-Strand Viruses. D. Kolakofski and B. W. J. Mahy, eds. Elseviers Scientific Publishers, Amsterdam.

8. Goldbach, R., and Peters, D. 1994. Possible causes of the emergence of tospovirus diseases. Semin. Virol. 5:113-120.

9. Gonsalves, D., and Trujillo, E. E. 1986. Tomato spotted wilt virus in papaya and detection of the virus in ELISA. Plant Dis. 70:501-506.

10. Griep, R. A., Van Twisk, C., Kerschbaumer, R. J., Harper, K., Torrance, L., Himmler, G., Van der Wolf, J. M., and Schots, A. 1999. pSKAP/S: An expression vector for single-chain Fv alkaline phosphatase fusion proteins. Prot. Expression Purif. 16:63-69.

11. Griep, R. A., Van Twisk, C., and Schots, A. 1999. Selection of Beet necrotic yellow vein virus-specific monoclonal antibodies from a semisynthetic combinatorial antibody library. Eur. J. Plant. Pathol. 105:147156.

12. Griep, R. A., Van Twisk, C., Van der Wolf, J. M., Van Beckhoven, J. R. C. M., and Schots, A. 1998. Selection of Ralstonia solanacearum race 3specific monoclonal antibodies from combinatorial libraries. Phytopathology 88:795-803.

13. Griffiths, A. D., Williams, S. C., Hartley, O., Tomlinson, I. M., Waterhouse, P., Crosby, W. L., Kontermann, R. E., Jones, P. T., Low, N. M., Allison, T. J., Prospero, T. D., Hoogenboom, H. R., Nissim, A., Cox, J. P. L., Harrison, J. L., Zaccolo, M., Gherardi, E., and Winter, G. 1994. Isolation of high affinity antibodies directly from large synthetic repertoires. EMBO J. 13:3245-3260.

14. Harper, K., Kerschbaumer, R. J., Ziegler, A., Macintosh, S. M., Cowan, G. H., Himmler, G., and Mayo, M. A. 1997. A scFv-alkaline phosphatase fusion-protein which detects potato leafroll luteovirus in plant extracts by ELISA. J. Virol. Methods 63:237-242.

15. Hoogenboom, H. R., Griffiths, A. D., Johnson, K. S., Chiswell, D. J., Hudson, P., and Winter, G. 1991. Multi-subunit proteins on the surface of filamentous phage: Methodologies for displaying antibody (Fab) heavy and light chains. Nucleic Acids Res. 15:4133-4137.

16. Huguenot, C., Van den Dobbelsteen, G., de Haan, P., Wagemakers, C. A. M., Drost, G. A. Osterhaus, A. D. M. E., and Peters, D. 1990. Detection of tomato spotted wilt virus using monoclonal antibodies and riboprobes. Arch. Virol. 110:47-62.

17. Kerschbaumer, R. J., and Himmler, G. 1999. Dedicated expression vectors for the production of diagnostic reagents. Pages 57-81 in: Recombinant Antibodies-Application in Plant Sciences and Plant Technology. K. Harper and A. Ziegler, eds. Taylor \& Francis, London.

18. Kerschbaumer, R. J., Hirschl, S., Kaufman, A., Ibl, M., Koenig, R., and Himmler, G. 1997. Single-chain Fv fusion proteins suitable as coating and detecting reagents in a double-antibody sandwich enzyme-linked immunosorbent assay. Anal. Biochem. 249:219-227.

19. Köhler, G., and Milstein, C. 1975. Continuous cultures of fused cells secreting antibodies of predefined specificity. Nature 256:495-497.

20. Law, M. D., and Moyer, J. W. 1990. A tomato spotted wilt-like virus with a serologically distinct N protein. J. Gen. Virol. 71:933-938.

21. Lindner, P., Guth, B., Wuelfing, C., Krebber, C., Steipe, B., Mueller, F., and Plückthun, A. 1992. Purification of native proteins from the cytoplasm and periplasm of Escherichia coli using IMAC and histidine tails: A comparison of proteins and protocols. Methods 4:41-56.

22. McCafferty, J., Griffiths, A. D., Winter, G., and Chiswell, D. J. 1990 Phage-antibodies: Filamentous phage displaying antibody variable domains. Nature 348:552-554.

23. Prins, M., and Goldbach, R. 1998. The emerging problem of tospovirus infection and nonconventional methods of control. Trends Microbiol. 6:31-35.

24. Prins, M., Resende, R. de O., Anker, C., Van Schepen, A., De Haan, P., and Goldbach, R. 1996. Engineered RNA-mediated resistance to tomato spotted wilt virus is sequence specific. Mol. Plant-Microbe Interact. 9: 416-418.

25. Resende, R. de O., De Haan, P., de Àvila, A. C., Kitajima, E. W., Kormelink, R., Goldbach, R., and Peters, D. 1991. Generation of envelope and defective interfering RNA mutants of tomato spotted wilt virus by mechanical passage. J. Gen. Virol. 72:2375-2383.

26. Roggero, P., Ogliara, P., Dellavalle, G., Lisa, V., Malavsi, F., and Adam, G. 1996. A general tospovirus assay using monoclonal antibodies against tomato spotted wilt virus glycoproteins. Acta Hortic. 431:167-175.

27. Sambrook, J., Fritch, E. F., and Maniatis, T. 1990. Molecular Cloning: A Laboratory Manual. Cold Spring Harbor Laboratory Press, Cold Spring Harbor, NY

28. Samuel, G., Bald, J. G., and Pittman, H. A. 1930. Investigations on spotted wilt of tomato. Commons. Aust. Counc. Sci. Ind. Res. Bull. 44.

29. Sherwood, J. L., Sanborn, M. R., Keyser, G. C., and Meyers, L. D. 1989. Use of monoclonal antibodies in detection of tomato spotted wilt virus. Phytopathology 79:61-64.

30. Susi, P., Ziegler, A., and Torrance, L. 1998. Selection of single-chain variable fragment antibodies to black currant reversion associated virus from a synthetic phage display library. Phytopathology 88:230-233.

31. Tavladoraki, P., Benvenuto, E., Trinca, S., De Martinis, D., Cattaneo, A., and Galeffi, P. 1993. Transgenic plants expressing a functional singlechain Fv antibody are specifically protected from virus attack. Nature 366 : 469-472.

32. Tijsen, P. 1985. Preparation of enzyme-antibody or other enzyme-macromolecule conjugates. Pages 1-20 in: Laboratory Techniques in Biochemistry and Molecular Biology. Vol 15, Practice and Theory of Enzyme Immunoassays. R. H. Burdon and P. H. van Knippenberg, eds. Scientific Publishers, Amsterdam.

33. Ultzen, T., Gielen, J. J. L., Venema, F., Westerbroek, A., De Haan, P., Tan, M. L., Schram, A., Van Grinsven, M. Q. J. M., and Goldbach, R. 1995. Resistance to tomato spotted wilt virus in tomato hybrids. Euphytica 85: 159-168.

34. Vaughan, T. J., Williams, A. J., Pritchard, K., Osbourn, J. K., Pope, A. R., Earnshaw, J. C., McCafferty, J., Hodits, R. A., Wilton, J., and Johnson, K. 1996. Human antibodies with sub-nanomolar affinities isolated from a large non-immunized phage display library. Nat. Biotechnol. 14:309314 .

35. Wang, M., and Gonsalves, D. 1990. ELISA detection of various tomato spotted wilt isolates using specific antisera to structural proteins of the virus. Plant Dis. 74:154-158.

36. Yeh, S. D., and Chang, T. F. 1995. Nucleotide sequence of the $\mathrm{N}$ gene of watermelon silver mottle virus, a proposed new member of the genus tospovirus. Phytopathology 85:58-64.

37. Ziegler, A., Torrance, L., Macintosh, S. M., Cowan, G. H., and Mayo, M. A. 1995. Cucumber mosaic cucumovirus antibodies from a synthetic phage display library. Virology 214:235-238. 